\title{
ДОРОГОЙ ЧИТАТЕЛЬ!
}

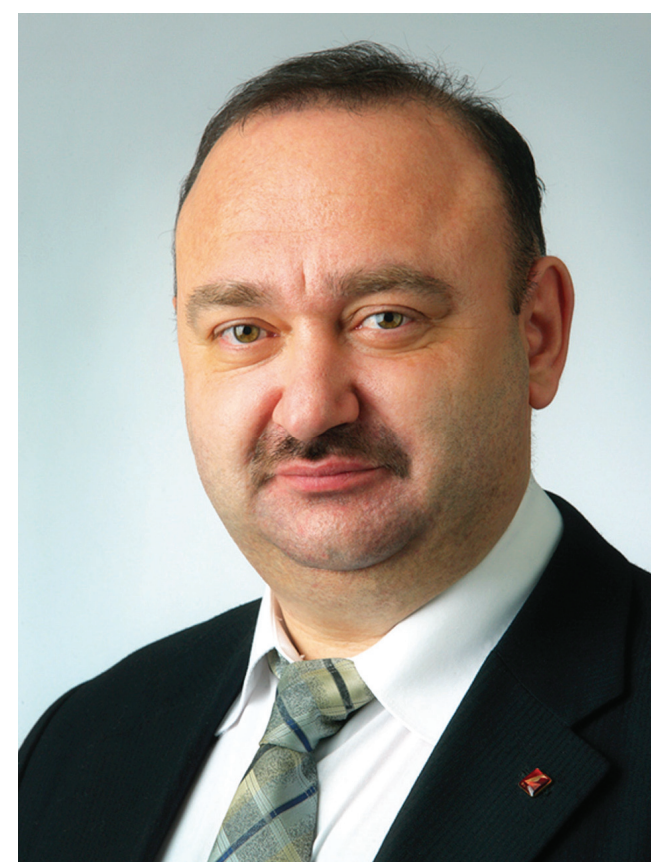

ПереА Вами очереАной, ставший уже традиционным, тематический номер, посвященный абдоминальной хирургии и не только.

В 2000 г. по инициативе профессора Г.К. Жермова и подАержке главы администрации ЗАТО Северск Н.И. Кузьменко в мало кому известном в то время городе быи открыт Северский гастроэнтерологический центр СО РАМН, работы которого приводили в изумление признанных корифеев хирургии и онкомогии. В 2002 г. Северский гастроцентр сменил статус и перешел поА «крышу» Сибирского госуАарственного меАицинского университета. На протяжении 11 мет НИИ гастроэнтерологии СибГМУ продолжал развиваться, оказывая специализированную высокотехнологичную меАицинскую помощь жителям Томской области и близлежащих регионов. Научная и клиническая работа, провоАимая в НИИ гастроэнтерологии, заскужила признание и ученых и пациентов. За этот периоА под руководством Г.К. Жерлова было защищено более 10 Аокторских и 30 кандидатских Аиссертаций. В свет вышло 10 монографий, более 100 статей в центральных российских и зарубежных журналах. Было получено более 60 патентов на изобретение. В 2013 г. в силу обстоятемьств НИИ гастроэнтерологии, уже носящий к тому времени имя своего основателя и первого руководителя Г.К. Жерлова, вновь смения юридическую принадлежность, став самостоятельным учрежАением в структуре зАравоохранения Томской области.
Но и сегоАня, спустя 15 мет со Аня открытия, несмотря на смену вывески, в «северский гастроцентр к Жерлову» за современной меАицинской помощью приезжают сотни пациентов от Урала до Аальнего Востока. КажАый год хирургами МеАицинского центра им. Г.К.Жерлова проводятся более 400 сложнейших операций, в том числе более 150 высокотехнологичных (органосохраняющих и органомоделирующих). Большая часть из них - по разработанным профессором Жерловым уникальным методикам, способным восстанавливать или максимально компенсировать функции пищеварительной системы посме перенесенного недуга, но не только. Сегодня очень много говорят о «fast track хирургии», которая преАставляет собой комплекс мечебных мероприятий, подразумевающий современный поАхоА на АО-, интра- и послеоперационном этапах ведения пациентов, совокупный результат которых заключается в уменьшении осложнений, послеоперационной боли, стрессовых реакций и Аисфункций органов, а также в ранней реабилитации пациентов. Снижение количества времени пребывания в стационаре, более быстрое возвращение к нормальной жизни и труАу, и, соответственно, уменьшение стоимости мечения, - преимущества мультимодальной стратегии ведения хирургических больных. А веАь все это очень широко использовалось в клинике, руководимой Георгием Киримловичем, еще в 1980-1990-х гг. и составляло краеугольный камень идеологии Жерлова, направленной на скорейшее выздоровмение больного.

Но главное богатство Центра - это сотруАники, среАИ которых Ава Аоктора и Пять КанАИАатов меАицинских наук, все врачи первой и высшей категории, а также среАний и млаАший меАицинский персонал, вопмощающий в жизнь идеи своего Учитемя.

В Центре всегда был силен симбиоз науки и практики. Основная научная тема - хирургическая гастроэнтерология и онкогастроэнтерология - безусловно, сохранится, но вместе с тем сейчас илет поиск новых, перспективных направлений на стыке наук. Прорабатывается вопрос о созАании на базе Центра отАеления Аля мечения больных с портальной гипертензией как первый шаг к мечте Г.К.Жерлова о трансплантации печени.

Начиная с 2012 г., Центр Жерлова проводит ставшую уже традиционной научно-практическую конференцию, посвященную актуальным 
вопросам абдоминальной хирургии и онкогастроэнтерологии. В этом номере мы продолжаем преАставлять результаты наиболее актуальных исслеАований, проводимых в области абАоминальной хирургии и онкомогии.

Четыре работы преАставлены нашими комлегами из г. Новокузнецка.

Н.А. Алексеев и соавт. преАставили результаты применения интраоперационной антеграАной энАоскопической папимлосфинктеротомии у пациентов с холангиолитиазом и патологией АИстального отАела холедоха. Использование Аанной метоАики позволимо снизить специфические осложнения ретроградной эндоскопической папиляосфинктеротомии и расширить возможности малоинвазивных вмешательств.

В работе А.А. Фаева и соавт. изучены непосреАственные и отАаленные резукьтаты хирургического мечения 353 пациентов с неотможными заболеваниями органов брюшной полости с использованием технологии еАиного мапароскопического Аоступа. Авторы убеАительно показали, что результаты операции через еАиный мапароскопический Аоступ сопоставимы с традиционными мапароскопическими вмешатемьствами по качеству жизни, позволяя Укучшить отАельные показатеки послеоперационного периода.
Статья С.В. Быстрова с соавт. отражает плоА комлективного труаа хирургов и патоморфологов, которые рассматривают морфологические особенности течения хронического холецистита при желчнокаменной болезни. В ходе Аискуссии авторы пришли к вывоАу о том, что речь можно вести о хронической эмпиеме желчного пузыря, но в имеющейся на Аанный момент классификации хомециститов Аанного понятия нет. Таким образом, вопрос остается открытым.

Применению малоинвазивных методик повящена работа А.И. Неймарк и соавт. (г. Барнаум). Авторы Аоказывают, что ретроперитонеоскопический метод позволяет УАалить конкремент и восстановить отток мочи из почки оАновременно, значительно сокращает сроки нетрудоспособности и меАикаментозную нагрузку на организм пациента.

Наиболее интересные тезисы работ, преАставленных на конференции, завершают выпуск журнала.

В заключении, в канун Нового 2016 года, хочется пожелать нам всем зАоровья, мирного неба и спокойной работы на бцаго наших пациентов.

С уважением, директор Медицинского изентра им. Г.К. Жерлова, профессор А. Кошель 